\title{
Ocean overturning since the Late Cretaceous: Inferences from a new benthic foraminiferal isotope compilation
}

\author{
B. S. Cramer, ${ }^{1,2}$ J. R. Toggweiler, ${ }^{3}$ J. D. Wright, ${ }^{4}$ M. E. Katz, ${ }^{5}$ and K. G. Miller ${ }^{4}$
}

Received 1 September 2008; revised 7 July 2009; accepted 3 September 2009; published 23 December 2009.

[1] Benthic foraminiferal oxygen isotopic $\left(\delta^{18} \mathrm{O}\right)$ and carbon isotopic $\left(\delta^{13} \mathrm{C}\right)$ trends, constructed from compilations of data series from multiple ocean sites, provide one of the primary means of reconstructing changes in the ocean interior. These records are also widely used as a general climate indicator for comparison with local and more specific marine and terrestrial climate proxy records. We present new benthic foraminiferal $\delta^{18} \mathrm{O}$ and $\delta^{13} \mathrm{C}$ compilations for individual ocean basins that provide a robust estimate of benthic foraminiferal stable isotopic variations to $\sim 80 \mathrm{Ma}$ and tentatively to $\sim 110 \mathrm{Ma}$. First-order variations in interbasinal isotopic gradients delineate transitions from interior ocean heterogeneity during the Late Cretaceous $(>\sim 65 \mathrm{Ma})$ to early Paleogene (35$65 \mathrm{Ma})$ homogeneity and a return to heterogeneity in the late Paleogene-early Neogene (35-0 Ma). We propose that these transitions reflect alterations in a first-order characteristic of ocean circulation: the ability of winds to make water in the deep ocean circulate. We document the initiation of large interbasinal $\delta^{18} \mathrm{O}$ gradients in the early Oligocene and link the variations in interbasinal $\delta^{18} \mathrm{O}$ gradients from the middle Eocene to Oligocene with the increasing influence of wind-driven mixing due to the gradual tectonic opening of Southern Ocean passages and initiation and strengthening of the Antarctic Circumpolar Current. The role of wind-driven upwelling, possibly associated with a Tethyan Circumequatorial Current, in controlling Late Cretaceous interior ocean heterogeneity should be the subject of further research.

Citation: Cramer, B. S., J. R. Toggweiler, J. D. Wright, M. E. Katz, and K. G. Miller (2009), Ocean overturning since the Late Cretaceous: Inferences from a new benthic foraminiferal isotope compilation, Paleoceanography, 24, PA4216, doi:10.1029/2008PA001683.

\section{Introduction}

[2] Benthic foraminiferal $\delta^{13} \mathrm{C}$ and $\delta^{18} \mathrm{O}$ records derived from deep-sea cores provide an unparalleled image of the past structure of the ocean interior. Whole-ocean benthic foraminiferal $\delta^{18} \mathrm{O}$ changes reflect a combination of surface temperature of deep water source regions (high latitudes) and global ice volume, while $\delta^{13} \mathrm{C}$ changes provide a constraint on carbon transfer between the ocean, atmosphere, and sediments. Interbasinal $\delta^{18} \mathrm{O}$ and $\delta^{13} \mathrm{C}$ differences reflect density and nutrient contrasts within the ocean, more generally reflecting the degree of homogeneity of the interior ocean. No other paleoceanographic proxy has been measured as extensively in both temporal and geographic terms. Trends derived from compilations of these data have been analyzed for insights into the evolution of high-latitude temperatures [Emiliani, 1954, 1961; Shackleton and Kennett, 1975; Savin et al., 1975; Miller et al., 1987a], as a framework for dis-

\footnotetext{
${ }^{1}$ Department of Geological Sciences, University of Oregon, Eugene, Oregon, USA.

${ }^{2}$ Now at Theiss Research, Eugene, Oregon, USA.

${ }^{3}$ Geophysical Fluid Dynamics Laboratory, NOAA, Princeton, New Jersey, USA.

${ }^{4}$ Department of Earth and Planetary Sciences, Rutgers University, Piscataway, New Jersey, USA.

${ }^{5}$ Department of Earth and Environmental Sciences, Rensselaer Polytechnic Institute, Troy, New York, USA.
}

Copyright 2009 by the American Geophysical Union. 0883-8305/09/2008PA001683\$12.00 cussion of Cenozoic climate change [Zachos et al., 2001, 2008], and to investigate the relative strength of different deepwater source regions [Wright and Miller, 1996; Poore et al., 2006]. Although these syntheses provide first- and second-order views of Cenozoic thermal evolution and the evolution of nutrient gradients in the Neogene, no comprehensive reconstruction of Cenozoic interbasinal isotopic, both $\delta^{13} \mathrm{C}$ and $\delta^{18} \mathrm{O}$, gradients has been published.

[3] Reconstructing the relative strengths of different deepwater source regions has been a focus of paleoceanographic research [Curry and Lohmann, 1982; Oppo and Fairbanks, 1987; Woodruff and Savin, 1989; Wright et al., 1991; Pak and Miller, 1992; Wright and Miller, 1996; Corfield and Norris, 1996; Rosenthal et al., 1997; Thomas et al., 2003; Thomas, 2004; Poore et al., 2006]. The primary regions of deepwater formation in the modern ocean are in the North Atlantic (North Atlantic deepwater: NADW) and near Antarctica in the Atlantic sector of the Southern Ocean (Antarctic Bottom Water: AABW). NADW and AABW have distinct nutrient and density (temperature and salinity) signatures that trace their penetration from north and south. The paradigm of bipolar water masses, generalized for the past as Northern Component Water (NCW) and Southern Component Water (SCW), has served as a framework for paleoceanographic reconstruction of deep water source regions.

[4] While substantially contributing to our understanding of circulation patterns within the ocean interior, the focus on traceable water masses has (1) reinforced a conceptualization of overturning circulation as the conveyor-like net flow of 
water connecting regions of deepwater formation with regions of upwelling [Broecker, 1991], (2) overemphasized the role of deep water production in driving the overturning circulation, and (3) led to the misconception that, if the sort of distinct water masses seen today cannot be found in the past, the overturning circulation may be assumed to have been weaker.

[5] We view the production of deep water as a secondorder characteristic of ocean overturning, resulting from the more fundamental first-order process of upwelling and removal of deep water from the interior. By this way of thinking, the rate and pattern of ocean overturning circulation is dictated by the way that dense deep water is brought back to the surface, a process that requires an input of energy from the winds and secondarily from tidal mixing [Wunsch, 2002]. Upwelling associated with the wind-driven Antarctic Circumpolar Current (ACC) is the dominant mode of water transport from the ocean interior to the surface in the modern ocean. The ACC sets the density structure for the ocean interior from the Southern Ocean to high northern latitudes [Toggweiler and Samuels, 1998] and isolates Antarctica oceanographically from the rest of the ocean, enabling the distinctive density $\left(\delta^{18} \mathrm{O}\right)$ and nutrient $\left(\delta^{13} \mathrm{C}\right)$ characteristics of NADW and AABW [Toggweiler and Bjornsson, 2000]. The ACC is the engine and fundamental organizing feature of the modern ocean, responsible for the density structure, deep circulation, NCW and SCW.

[6] Recent ocean circulation modeling efforts have demonstrated that the relative strength of different deep-water source regions, the second-order feature of ocean circulation, is sensitive primarily to ocean temperature [de Boer et al., 2007, 2008]. The effect of low polar salinities in negating the effect of low polar temperatures on the density of seawater is greatest at low temperatures $\left(<4^{\circ} \mathrm{C}\right)$. Thus, the overturning may be split into thermal and haline regimes that are dominant in warmer and colder oceans, respectively. For a given mechanical energy input, deep-water formation should be more vigorous in more places in warmer climates [de Boer et al., 2007]. The thermal/haline split explains the insignificance of deepwater formation in the North Pacific: deep water production in the high-salinity North Atlantic is dominant in the modern cold ocean [de Boer et al., 2008].

[7] We use new compilations of Upper CretaceousCenozoic deep-sea $\delta^{13} \mathrm{C}$ and $\delta^{18} \mathrm{O}$ records separated by ocean basin to illustrate large-scale changes in the homogeneity of the ocean interior over the last $80 \mathrm{Myr}$. Separate isotopic compilations from the North Atlantic, South Atlantic/Subantarctic, tropical Pacific, and high-latitude Southern Ocean basins are used to generate records of interbasinal isotopic differences. The separation of trends by basin provides a reconciliation of differences between trends calculated from previous data compilations [Miller et al., 1987a; Zachos et al., 2001]. The addition of new data also allows the calculation of an isotopic trend for much of the Cretaceous $(<110 \mathrm{Ma})$, an important extension of a curve that has become a default primary long-term climate indicator. We interpret the $\delta^{13} \mathrm{C}$ and $\delta^{18} \mathrm{O}$ gradients simply as a simple reflection of the homogeneity of the ocean interior, with the assumption that the degree of homogeneity primarily reflects the interplay of the two processes outlined above: the ability of the ocean interior to capture the mechanical energy from winds, and the temperature of the ocean influencing the balance between thermal and haline circulation.

\section{Methods}

[8] We compiled benthic foraminiferal $\delta^{18} \mathrm{O}$ and $\delta^{13} \mathrm{C}$ data from publications spanning 25 years obtained from Deep Sea Drilling Project (DSDP) and Ocean Drilling Program (ODP) cores (Figures 1, 2, and 3 and auxiliary material). ${ }^{1}$ Ages for the isotopic data either from the original publication or later publications were adjusted to the timescale of Gradstein et al. [2004] by linear interpolation between equivalent ages for magnetic polarity reversals, with minimal modification except in the middle to late Eocene, where biostratigraphic data often conflicted with isotope stratigraphy. Age models for middle to late Eocene records that resolve the middle Eocene $\delta^{18} \mathrm{O}$ minimum (MECO, $\sim 39.8-40.6$ Ma [Bohaty and Zachos, 2003; Bohaty et al., 2009]) were recalibrated using linear interpolation between that event and the earliest Oligocene $\delta^{18} \mathrm{O}$ maximum (Oi-1). We provide ages relative to both Gradstein et al. [2004] and Cande and Kent [1995] in the data sets (see auxiliary material).

[9] Vital effects in different species of benthic foraminifera can result in systematic interspecies isotopic offsets. We used only data generated from monogeneric samples of Cibicidoides (including samples identified as Planulina wuellerstorfi and P. renzi) for the Oligocene to present. Data generated using monogeneric samples of Cibicidoides, Oridorsalis, Nuttallides, or Stensioina (Gavelinella) were used for the Paleocene and Eocene, with values corrected to Oridorsalis using established correction factors [Katz et al., 2003a]. Due to sparse Cretaceous data, all monogeneric Cretaceous samples were used and corrected to Oridorsalis using established correction factors [Katz et al., 2003a] where available and ad hoc correction factors for other data. Following Shackleton [1974], most of the paleoceanographic community has assumed that Cibicidoides $\delta^{18} \mathrm{O}$ values are $0.64 \%$ less than equilibrium with seawater, but more recent work indicates that Cibicidoides tests are precipitated at isotopic equilibrium with seawater in $\delta^{18} \mathrm{O}$ [e.g., Bemis et al., 1998; Costa et al., 2006] as well as $\delta^{13}$ C. We plot and tabulate data corrected to Cibicidoides, the genus analyzed for most of the data in our compilation, including all of the Neogene data.

[10] In estimating a trend through the data, our intention is to extract variability of similar timescale ( $>1.5 \mathrm{Myr}$; Figure 4$)$ throughout the last $80 \mathrm{Myr}$. Late Paleogene-Neogene data is considerably oversampled for this purpose and has been synthesized previously with methods better adapted to show short-timescale variability [e.g., Poore et al., 2006]. Our goal also is to synthesize data from multiple sites without overemphasizing those sites with highest sampling interval and to avoid the creation of artifactual temporal variability due to the juxtaposition of data from geographically disparate locations, both of which have introduced biases into previous compilations. Our method assumes that differences in isoto-

\footnotetext{
${ }^{1}$ Auxiliary material data sets are available at $\mathrm{ftp}$ ://ftp.agu.org/apend/pa/ 2008 pa001683.
} 

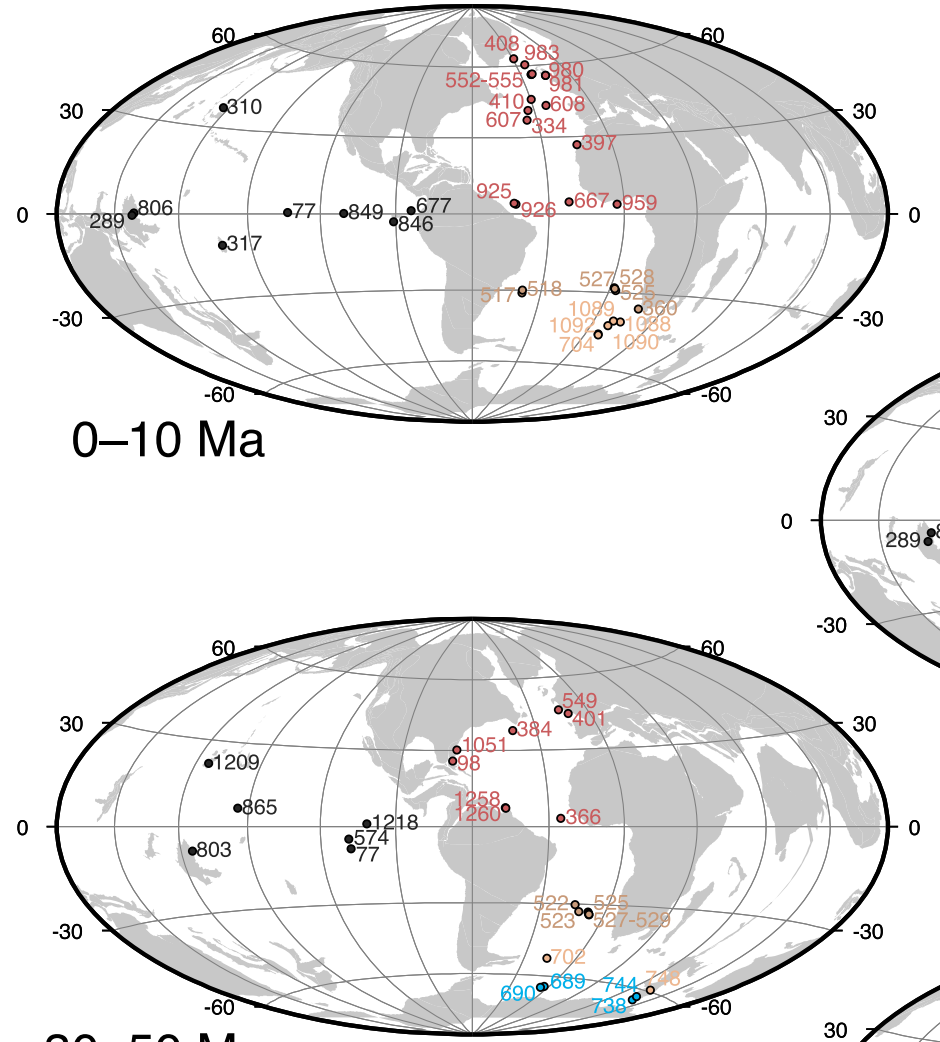

$30-50 \mathrm{Ma}$

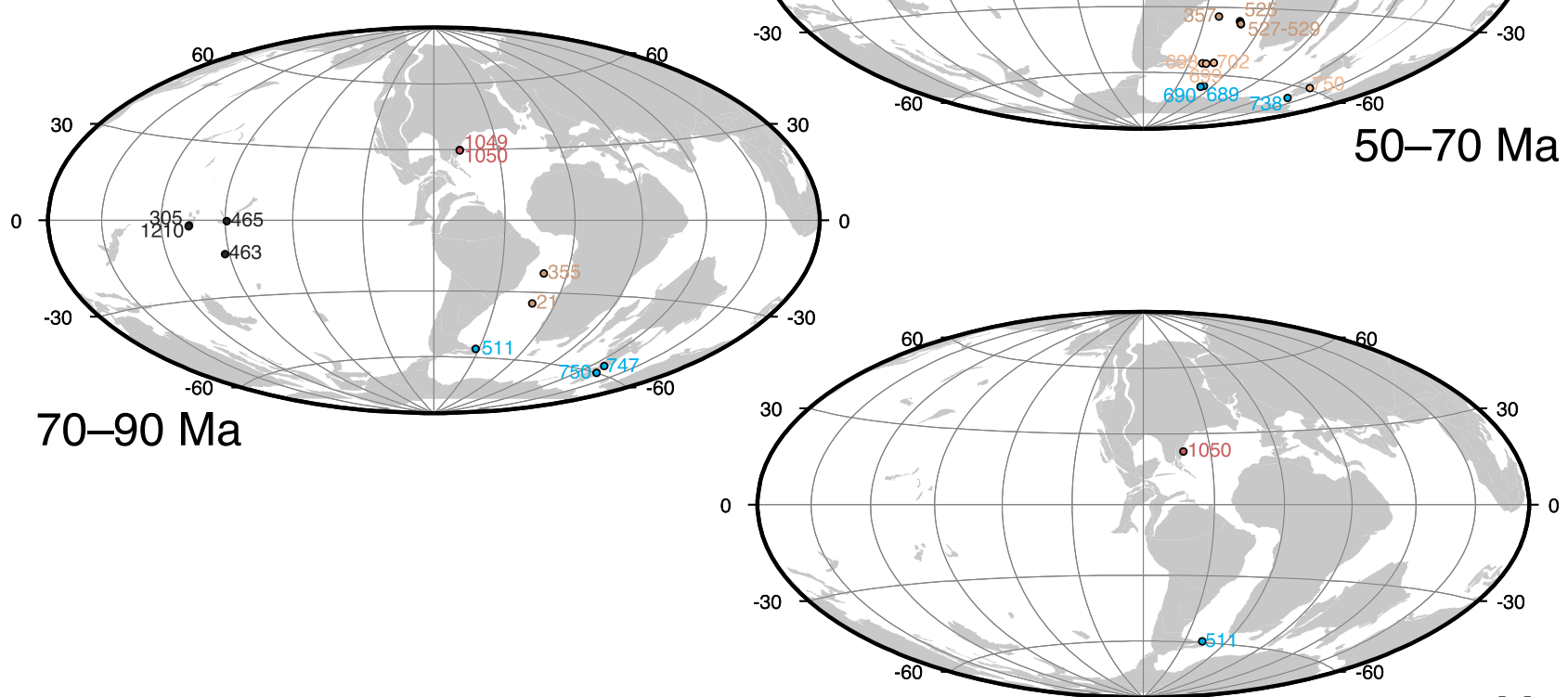

90-110 Ma

Figure 1. Paleogeographic reconstructions for the Cenozoic showing sites used for estimating isotopic trends in 20 Myr intervals. Records from each site generally do not span the full $20 \mathrm{Myr}$ interval. Paleogeographic reconstructions are for the midpoint of the interval (present-day for the $0-10 \mathrm{Ma}$ interval) and were drawn using the Internet-based tool available from the Ocean Drilling Stratigraphic Network [Brückmann et al., 1999; Hay et al., 1999]. 


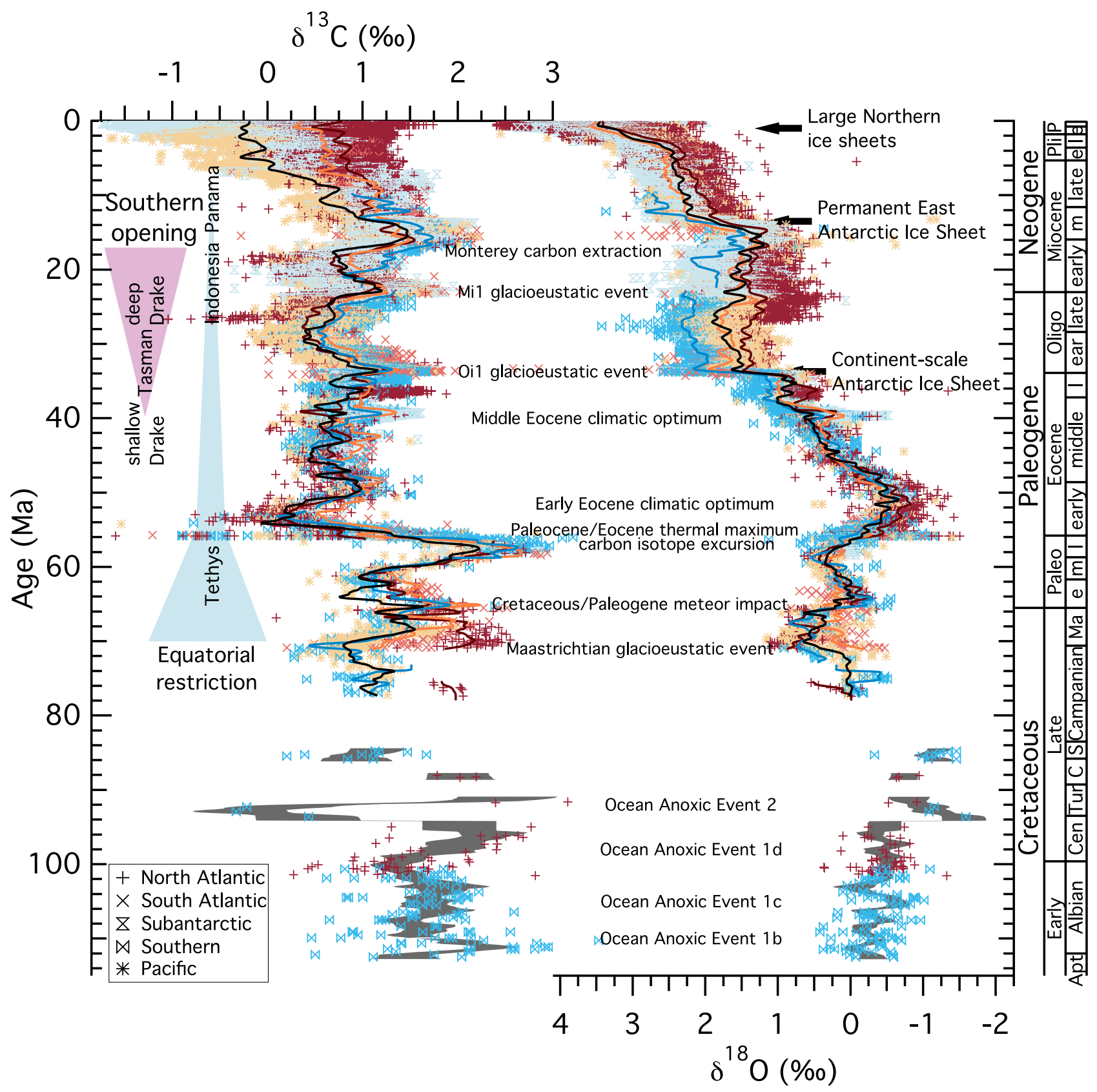

Figure 2. Global compilation of benthic foraminiferal isotope records with best fit trends (see section 2). Separate trends are shown for the Pacific, North/equatorial Atlantic, South Atlantic/subantarctic Southern, and high-latitude Southern oceans. In the older Cretaceous, the 95\% confidence interval for the trend through the available data is shown rather than the best fit. Individual data points have been corrected to Cibicidoides-equivalent values. Data and calculated trends are tabulated in the auxiliary material.

pic values from various sites entirely reflect systematic geographic variability rather than site-wise biased sampling of temporal variability. To the extent that is not the case, our smooth curve underestimates the true variability of the deepocean isotopic reservoir.

[11] Data for individual sites were interpolated to $0.1 \mathrm{Myr}$ resolution using a local linear regression method with tricube weighting in $0.8 \mathrm{Myr}$ width bins. This provides a more stable bandwidth response in data with highly variable sampling interval than the commonly used Loess algorithm [Cleveland and Devlin, 1988], in which the number of data points used in each linear regression is fixed and independent of the local sampling interval. Basin-wide trends were estimated through the site-wise interpolated data using an iterative process: an estimated trend was calculated as the local linear regression through site-wise interpolated data, the offset between interpolated values for each site and the estimated trend was calculated and smoothed using a Gaussian low-pass filter 


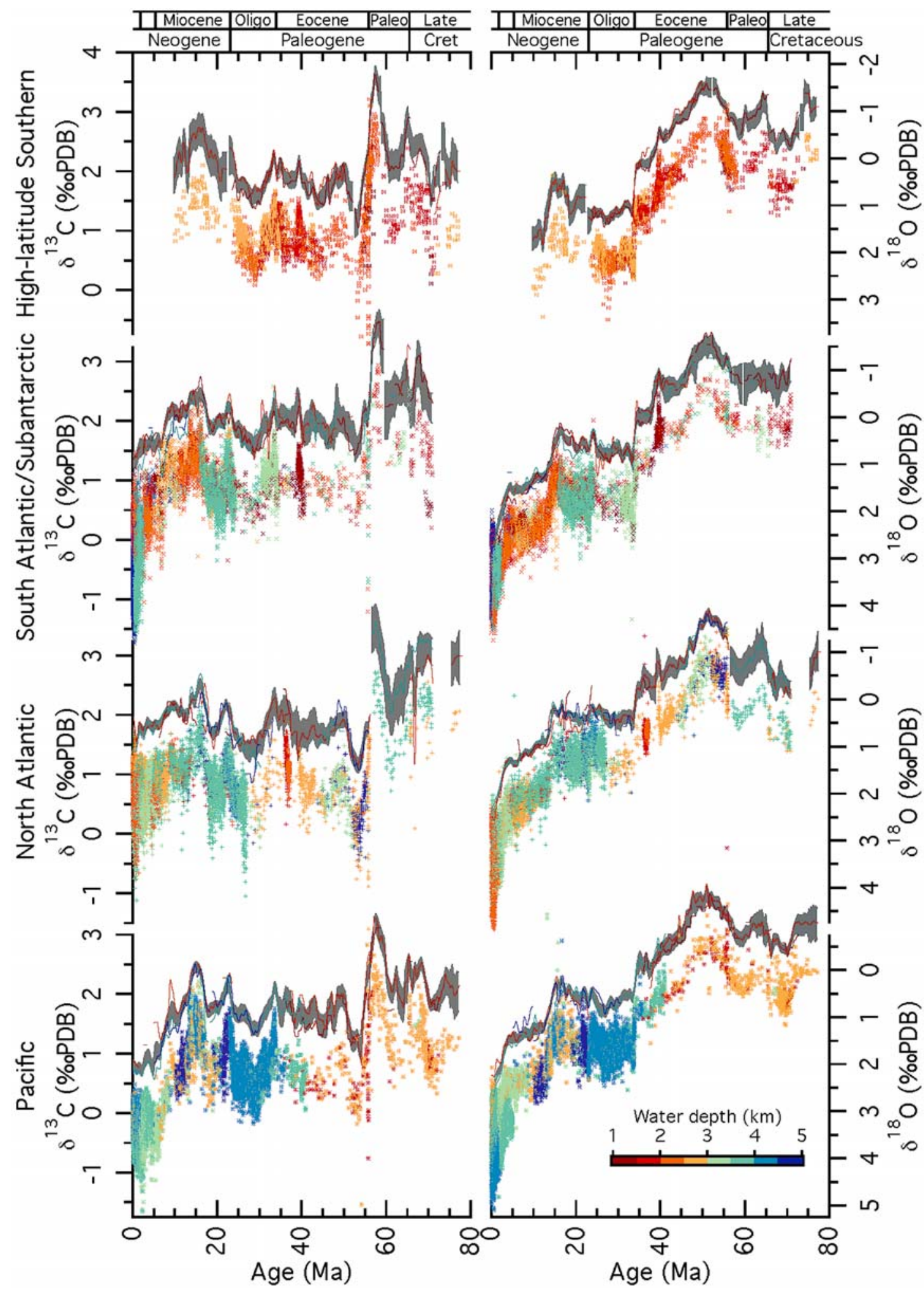

Figure 3. Trends projected through compilations of data for the tropical Pacific, North/equatorial Atlantic, South Atlantic/subantarctic Southern, and high-latitude Southern oceans. Individual data points have been corrected to Cibicidoides-equivalent values and are plotted in shades calibrated to paleowater depth. Trends are offset from the data by $1 \%$ for clarity. The $90 \%$ confidence interval for the trend projected through all data from each basin is shown as a gray swath with trends for paleodepth-separated subsets of the data superimposed: $1000-2000 \mathrm{~m}$ (dark red), 2000-3000 m (orange), 3000-4000 m (blue-green), and $>4000 \mathrm{~m}$ (dark blue). 


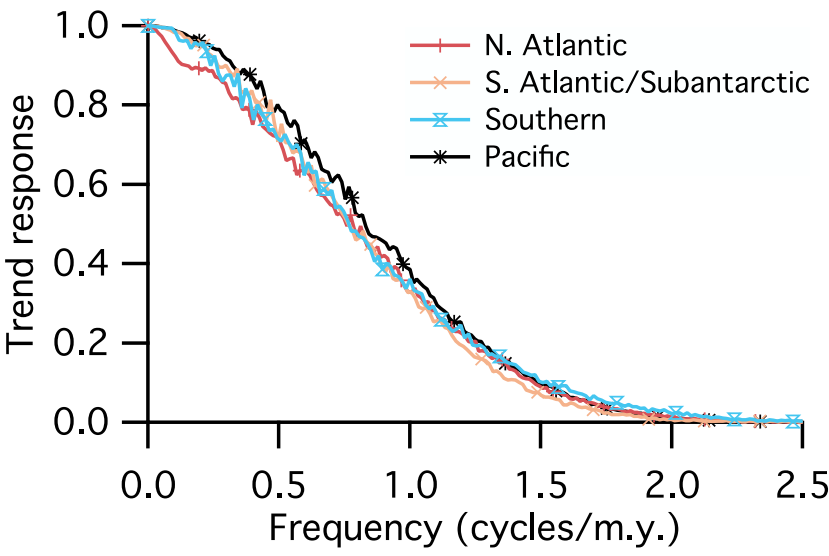

Figure 4. Frequency response for the trend estimator used in this study. The frequency response is subject to variations in sampling interval, distribution of data among sites, and end effects at the ends of records from individual sites, data gaps, and the ends of the estimated trend. A frequency response for each basinal trend is shown, estimated using synthetic data sets of sinusoidal curves, one for each Fourier frequency for the trend curve, sampled according to the actual data distribution.

with 0.1 response at $10 \mathrm{Myr}$ period, and a new trend estimate was calculated through the offset-corrected site-wise interpolated data. The process was repeated until the estimated trend converged to a small $(<0.001 \%)$ variation between iterations.

[12] A 90\% confidence envelope was calculated around the trend using a bootstrapping approach. We subtracted the trend from each data point (noninterpolated) to obtain a population of residual values. Examination of the histogram of this population for each ocean basin shows that the residual values are approximately normally distributed and that the distribution is constant through time except in the interval $<2 \mathrm{Ma}$. Synthetic data sets were constructed by replacing each original data point with the age-equivalent trend value and adding a randomly selected value from a normal distribution fit to the residual population; trends were calculated for each synthetic data set using the procedure described in the previous paragraph. Using 1000 synthetic trends, the $90 \%$ confidence envelope surrounding the trend is defined by the 5th and 95th percentile for each point in the trend estimate.

[13] The resulting confidence envelope reflects the uncertainty in the trend resulting from the distribution of data among different sites and through time. It neglects the uncertainty in the age calibration of data, but overestimates the overall uncertainty by assuming that the residual population is randomly distributed in time and uncorrelated among sites. In fact, due to orbital forcing of climate, the residual population should be expected to be largely cyclical in time and highly correlated among sites. The confidence envelope also neglects the uncertainty in the basin-wide isotopic trend estimates due to geographic bias in the distribution of sites.

[14] One concern in projecting trends through paleoceanographic data over long time periods is that, due to seafloor spreading and subduction, the drilled sites are biased toward shallower water depth with increasing age. Paleodepths were estimated for each data point in our compilation using backtracking, which takes into account the thermal subsidence and sediment loading of the crust through time [Sclater et al., 1971; Berger and Winterer, 1974; Parsons and Sclater, 1977; Miller et al., 1987b; Stein and Stein, 1992]. We use equations based on the empirical approximation for crustal subsidence through time found by Stein and Stein [1992]:

$$
\begin{aligned}
\text { Paleodepth }= & \text { InitialDepth }+\mathrm{S}(\text { CrustAge }- \text { SampleAge }) \\
& -0.66 \times(\text { CrustDepth }- \text { SampleDepth })
\end{aligned}
$$

where

$$
\begin{aligned}
\text { InitialDepth }= & \text { PresentDepth }-\mathrm{S}(\text { CrustAge })-0.66 \\
& \times \text { CrustDepth }
\end{aligned}
$$

and

$\mathrm{S}(x)=\left\{\begin{array}{ll}365 \sqrt{x} & \text { forCrustAge }<20 \mathrm{Ma} \\ 3051 \times\left(1-\frac{8}{\pi^{2}} e^{-0.0278 \mathrm{x}}\right) & \text { forCrustAge } \geq 20 \mathrm{Ma}\end{array}\right.$.

[15] Basement age and total sediment thickness for each site were taken either from DSDP and ODP site reports or from map data downloaded from ftp://ftp.es.usyd.edu.au/ pub/agegrid/2008/Grids and http://www.ngdc.noaa.gov/ $\mathrm{mgg} / \mathrm{sedthick} / \mathrm{sedthick}$.html. A plot of the paleodepths versus sample age demonstrates that the older samples are somewhat biased toward shallower depths (Figure 5). Separate trends calculated for subsets of the data in $1000 \mathrm{~m}$ intervals generally fall within the $90 \%$ confidence envelope for the trend calculated through all data (Figure 3 ). Where that is the

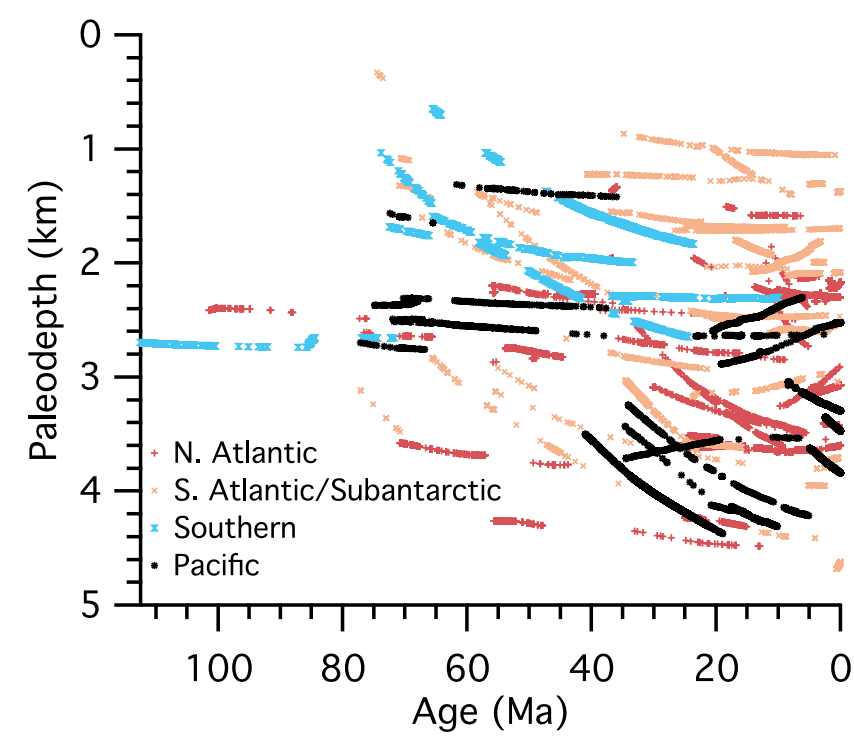

Figure 5. Paleodepths for all samples in the isotopic compilation. Note that only data for samples with paleodepth $>1000 \mathrm{~m}$ are shown in Figures 2 and 3 and only these samples were used in trend calculations. 


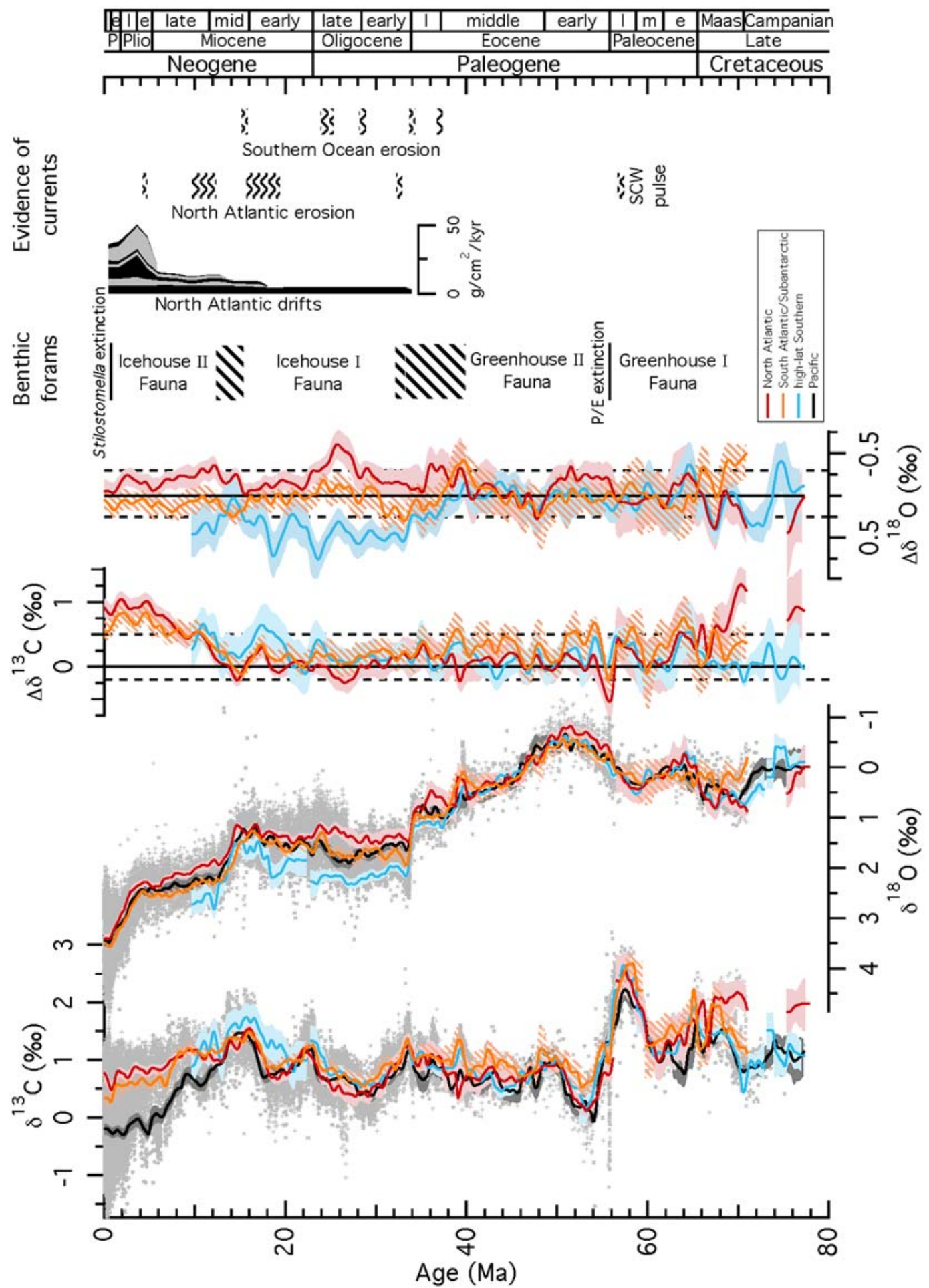

Figure 6. Carbon and oxygen isotopic trend estimates for individual ocean basins (Figure 3 ) and difference $\left(\Delta \delta{ }^{13} \mathrm{C}\right.$ and $\left.\Delta \delta^{18} \mathrm{O}\right)$ curves with the Pacific basin (Pacific therefore plots as a vertical line at 0 ). Difference curves were calculated by subtracting the trend estimated for the Pacific compilation from trends estimated for individual basins and smoothing with a Gaussian low-pass filter $(0.2$ response at a period of $3 \mathrm{Myr}$ ). Trends and interbasinal differences with 90\% confidence envelopes are tabulated in the auxiliary material. Changes in benthic foraminiferal communities are shown following Miller et al. [1992] and Thomas [1992a, 2007]. North Atlantic drift accumulation rates are taken from Wold [1994] and plotted following Wright and Miller [1996]. Timing of widespread depositional hiatuses is shown following Wright and Miller [1993] and Mountain and Miller [1992]. 


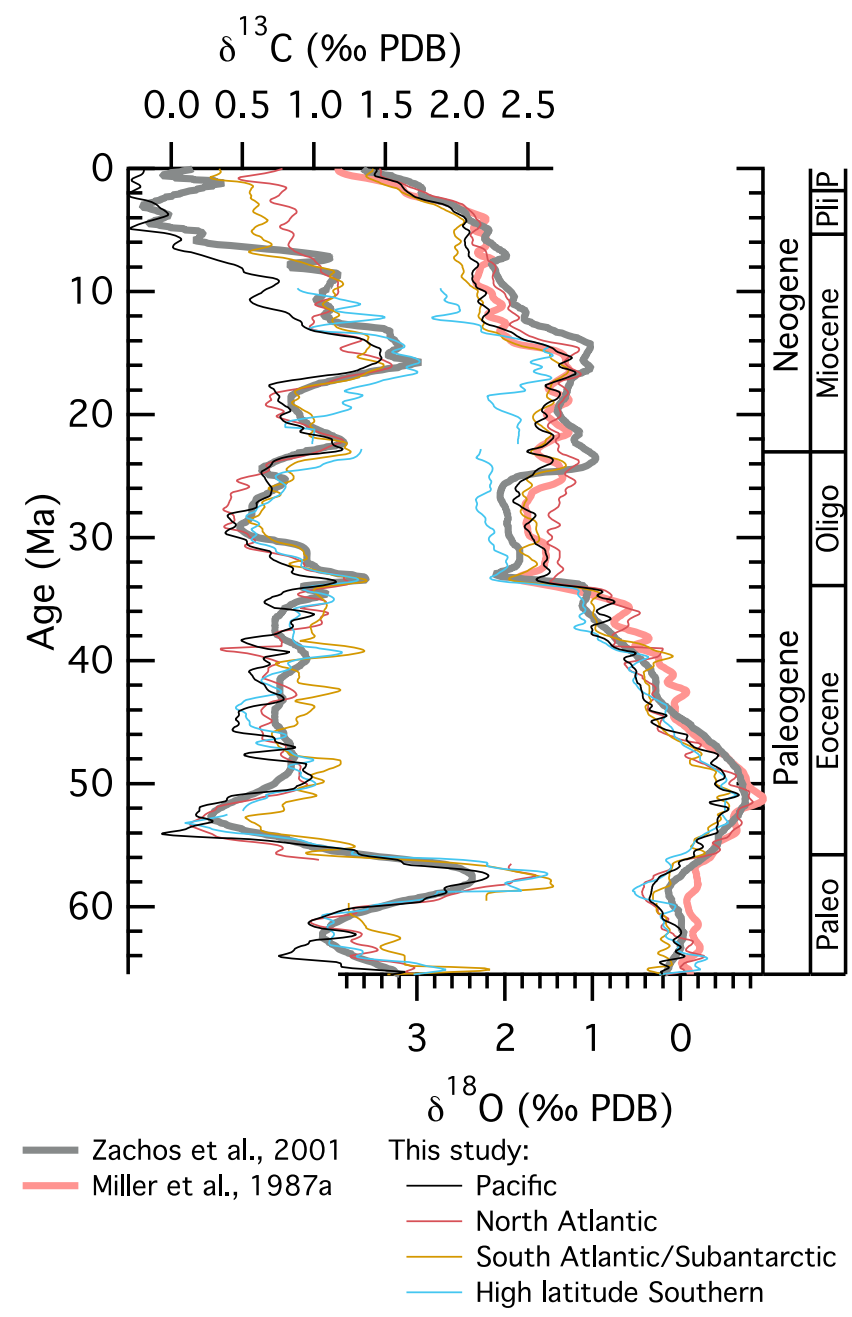

Figure 7. Comparison of global and basinal isotopic trend estimates from this paper with those of Miller et al. [1987a] (no $\delta^{13} \mathrm{C}$ published) and Zachos et al. [2001]. Differences between the three studies reflect both differences in data distribution (temporal and geographic) and statistical treatment of the data.

case, it implies that there is insufficient data to discriminate between trend bias due to paleodepth differences and the expected variation in trends calculated through different subsets of the data. We note that intervals with larger differences between trends calculated through different paleodepth subsets are also intervals with larger interbasinal differences (Figure 6). This is not unexpected: it implies that basin-tobasin differentiation and vertical stratification of the interior ocean are linked. Isotopic gradients in the Cretaceous interval may reflect vertical differentiation in the ocean, but this still contrasts with the homogeneity of the early Paleogene interval.

\section{Temporal Trends and Interbasinal Gradients}

[16] The Cenozoic deep ocean isotopic trends calculated here confirm the broad patterns shown in previous compilations (Figures 2 and 7): (1) a late Paleocene $\delta^{13} \mathrm{C}$ maximum followed by a large $\left(>2 \%\right.$ ) decrease in $\delta^{13} \mathrm{C}$ values into the early Eocene, (2) an extended $\delta^{18} \mathrm{O}$ maximum during the early Eocene climate optimum (EECO), (3) a $>4 \%$ increase in $\delta^{18} \mathrm{O}$ values from the early Eocene to the present, and (4) a $\sim 0.75 \%$ o $\quad \delta^{13} \mathrm{C}$ increase across the early/middle Miocene boundary followed by a $\sim 1.5 \%$ middle to late Miocene $\delta^{13} \mathrm{C}$ decrease. The long-term $\delta^{18} \mathrm{O}$ increase occurs in three steps that have been associated with major changes in the size of polar ice sheets: the earliest Oligocene glaciation of Antarctica (33-34 Ma, Oi-1 event [Miller et al., 1991; Zachos et al., 1992]), middle Miocene development of a permanent East Antarctic ice sheet (12-14 Ma [Wright et al., 1992; Flower and Kennett, 1994]), and late Pliocene increase in large-scale Northern Hemisphere ice sheets (2.6-2.7 Ma [Shackleton et al., 1984]).

[17] Our reconstruction differs substantially from that of Zachos et al. [2001] in the late Oligocene and middle to late Miocene (Figure 7). The Pacific $\delta^{13} \mathrm{C}$ trend decreases throughout the middle to late Miocene (15-5 Ma) with a small increase from 11 to $9 \mathrm{Ma}$, similar to the trend calculated by Poore et al. [2006] but differing from the abrupt drop in the latest Miocene shown by Zachos et al. [2001]. In contrast with the large $(\sim 1 \%)$, abrupt $\delta^{18} \mathrm{O}$ decrease in the late Oligocene shown by Zachos et al. [2001], we show only small $(\sim 0.5 \%) \delta^{18} \mathrm{O}$ decreases in the late Oligocene Pacific and South Atlantic/Subantarctic trends as the initiation of a series of $\delta^{18} \mathrm{O}$ oscillations (the Mi events of Miller et al. [1991]) through the early Miocene. These differences result from our separation of compilations by basin and our method of calculating trends that minimizes artifacts due to differing data density and temporal extent among individual records. The trend calculated by Zachos et al. [2001] predominantly follows the trend from sites with highest sampling resolution: their late Oligocene $\delta^{18} \mathrm{O}$ decrease results from a switch from high-latitude Southern Ocean records (ODP Sites 689, 744, and 747) to the high-resolution record from South Atlantic ODP Site 929 (as noted by Ravizza and Zachos [2003] and Pekar et al. [2006]) while their late Miocene $\delta^{13} \mathrm{C}$ decrease occurs when the trend shifts to the high-resolution record from Pacific ODP Site 846.

[18] By extending the records into the Cretaceous, our compilation provides a longer context for the Cenozoic changes. In the context of the Cretaceous record, the middle Paleocene $\delta^{13} \mathrm{C}$ increase is not obviously unusual, with $\delta^{13} \mathrm{C}$ values similar to peak late Paleocene values occurring in the early Albian, Cenomanian, and Maastrichtian (Figure 2). This contrasts with bulk carbonate $\delta^{13} \mathrm{C}$ records which show an unusually large $\delta^{13} \mathrm{C}$ increase preceding the late Paleocene peak [Katz et al., 2005]. Similarly, the decrease in $\delta^{18} \mathrm{O}$ values into the early Eocene and subsequent increase to the late Eocene are not obviously unusual for the Cretaceous, with Cenomanian-Turonian and Santonian $\delta^{18} \mathrm{O}$ values lower than those of the early Eocene and high values in the Maastrichtian similar to those of the late Eocene. Notably, the best evidence for sea level lowering due to growth of ice on Antarctica during the Cretaceous is coincident with peak $\delta^{18} \mathrm{O}$ values in the Maastrichtian [Miller et al., 1999].

[19] Separation of stable isotope records by ocean basin allows a comprehensive reconstruction of interbasinal stable isotopic differences (Figure 6). In broad terms, this recon- 
struction provides the basis for a tripartite paleoceanographic division of the last $80 \mathrm{Ma}$ : large $(>0.5 \%$ ) interbasinal isotopic differences characterize the Late Cretaceous and late Paleogene-Neogene ocean, while the early Paleogene ocean was homogeneous with isotopic differences $<0.5 \%$. Late Cretaceous isotopic gradients have been previously documented and used to infer changes in deepwater circulation patterns [e.g., Barrera et al., 1997; Frank and Arthur, 1999]. The increase in interbasinal $\delta^{13} \mathrm{C}$ gradients during the Miocene has also been documented in previous more detailed studies [Woodruff and Savin, 1989; Wright et al., 1991; Wright and Miller, 1996; Billups, 2002; Poore et al., 2006], with our records confirming the divergence of the North Atlantic and Pacific in the middle Miocene (13-10 Ma) and divergence of the North Atlantic and South Atlantic/ Subantarctic in the late Miocene $(\sim 7 \mathrm{Ma})$. Although attempts have been made to use the minor isotopic gradients in the early Paleogene to infer patterns of deepwater circulation [Pak and Miller, 1992; Corfield and Norris, 1996], we emphasize the relative isotopic homogeneity of the early Paleogene as itself a significant observation [e.g., Sexton et al., 2006]. The increase in the Southern-Pacific Ocean $\delta^{18} \mathrm{O}$ difference from the middle Eocene to early Oligocene that marks the end of early Paleogene homogeneity has also not been previously noted. In section 4, we note other evidence that supports identification of the MaastrichtianPaleocene and middle Eocene-early Oligocene as intervals of major reorganization of ocean circulation, and summarize previously published hypotheses regarding the development of $\delta^{13} \mathrm{C}$ gradients in the Miocene. In section 5 we refer to previously published ocean circulation modeling experiments that provide a basis for interpreting the development of the large interbasinal $\delta^{18} \mathrm{O}$ gradients in the middle Eocene-late Oligocene.

\section{Reorganizations in the Ocean Interior}

[20] Changes in ocean circulation alter interior ocean ventilation, bottom water nutrient distributions, and deep currents. These effects are reflected in the fossil record of bottom-dwelling organisms, such as benthic foraminifera, and as changes in depositional mode in the sedimentary record. The largest extinction event among benthic foraminifera of the last $100 \mathrm{Myr}$ occurred at the Paleocene/Eocene boundary, while a series of more gradual extinctions and originations of benthic foraminiferal species occurred during (1) the late middle Eocene through earliest Oligocene, (2) the late early to early middle Miocene, and (3) the middle Pleistocene (Figure 6) [Miller et al., 1992; Thomas, 2007; Hayward et al., 2007]. Evidence from sediment distribution points to changes in deep current configuration during the Eocene-Oligocene transition, late early to middle Miocene, and Miocene-Pliocene transition (Figure 6) [Kennett, 1977; Wright and Miller, 1993, 1996].

[21] The timing of the Cretaceous-Paleogene reduction in interbasinal $\delta^{13} \mathrm{C}$ and $\delta^{18} \mathrm{O}$ gradients is somewhat obscured by the surface environment effects of the catastrophic $\mathrm{K} / \mathrm{Pg}$ boundary Chicxulub meteor impact [Alvarez et al., 1980; Hildebrand et al., 1991]. It is unlikely that this high-energy but transient event could have effected a long-term alteration of the ocean interior, especially since the event had minimal effect on benthic communities [e.g., Culver, 2003; Thomas, 2007]. Phytoplankton diversity did not recover for several million years following the impact event [Katz et al., 2004; Coxall et al., 2006]. The reduction of surface ocean export production to the deep sea apparently led to an extended reduction in surface to deep ocean $\delta^{13} \mathrm{C}$ gradients [e.g., D'Hondt et al., 1998; Coxall et al., 2006] which would result in a reduction in interbasinal benthic foraminiferal $\delta^{13} \mathrm{C}$ gradients regardless of changes to ocean circulation. Changes in benthic foraminiferal communities are concentrated at the Paleocene/Eocene thermal maximum (PETM), a catastrophic global warming event that resulted from a rapid input of isotopically light carbon into the ocean/atmosphere [Kennett and Stott, 1991; Thomas and Shackleton, 1996; Thomas, 1998; Katz et al., 1999; Sluijs et al., 2007]. An erosional event in the late Paleocene (seismic reflector $\mathrm{A}^{\mathrm{b}}$ ) just prior to the PETM has been attributed to an increase in SCW entering the Atlantic [Mountain and Miller, 1992; Katz et al., 1999]. Mountain and Miller [1992] speculated that this pulse resulted from tectonic opening of passages between the North Atlantic and Southern Ocean, which has also been invoked as an explanation of a temporary reduction in $\delta^{13} \mathrm{C}$ gradients during the Maastrichtian [Frank and Arthur, 1999]. An increase in $\varepsilon \mathrm{Nd}$ values from the Pacific over several million years spanning the $\mathrm{K} / \mathrm{Pg}$ boundary has been interpreted as evidence for a significant change in ocean circulation [Thomas, 2004]. It is possible that both the $\mathrm{K} / \mathrm{Pg}$ impact and PETM occurred during a long-term transition in the structure of the interior ocean, with the catastrophic environmental changes associated with those two events obscuring the slower changes in the structure of the ocean interior.

[22] Eocene benthic foraminiferal taxa were gradually replaced through a series of extinctions and originations beginning in the late middle Eocene and culminating in the earliest Oligocene glaciation of Antarctica (Oi-1 event [Tjalsma and Lohmann, 1983; Miller et al., 1991; Zachos et al., 1992; Miller et al., 1992; Thomas, 1992b, 2007]). The middle Eocene-early Oligocene is recognized as a transitional interval in numerous marine proxy records. Deep Pacific $\varepsilon \mathrm{Nd}$ values decreased in the middle Eocene, interpreted as reflecting increasing influence of a Southern Ocean deep water source [Thomas, 2004; Thomas et al., 2008], and an increase in Atlantic sector Southern Ocean $\varepsilon N d$ values indicates flow of water from the Pacific through the Drake Passage beginning immediately after the middle Eocene climatic optimum (MECO) [Scher and Martin, 2004, 2006], a $\sim 0.6$ Myr long interval of warming superimposed on the middle to late Eocene cooling trend [Bohaty and Zachos, 2003; Bohaty et al., 2009]. A series of carbonate accumulation events in the equatorial Pacific occurred in the middle to late Eocene, seen as precursors to the dramatic deepening of the carbonate compensation depth coincident with the Oi-1 event, with the largest of these also following the MECO [Lyle et al., 2006; Bohaty et al., 2009]. Variations in geographic patterns of productivity, and specifically an increase in Southern Ocean productivity, indicate a redistribution of surface ocean nutrients in the same interval (discussion by Schumacher and Lazarus [2004], Barker and Thomas [2004], and Berger [2007]). 
[23] In the sedimentary record, late Eocene hiatuses in the Southern Ocean [Wright and Miller, 1993] preceded an abrupt erosional pulse in the North Atlantic and Southern Ocean [Kennett, 1977; Miller and Tucholke, 1983; Mountain and Miller, 1992; Wright and Miller, 1996] and onset of drift deposition in the North Atlantic and North Pacific [Wold, 1994; Rea et al., 1995] at Oi-1, indicating a spin-up of deepocean currents. Consistent with these changes, a gradual increase in interbasinal $\delta^{18} \mathrm{O}$ gradients through the late Eocene culminated in an abrupt increase coincident with Oi-1 (Figure 6), indicating that the development of a more complex interior ocean density structure accompanied environmental changes that affected the benthic foraminiferal communities: primarily deep ocean nutrient distribution but potentially including corrosivity, dissolved oxygen, and temperature [Thomas and Gooday, 1996; Thomas, 2007]. The more complex interior ocean structure is also reflected in the more depth stratified character of Oligocene benthic foraminiferal taxa as compared to the Eocene, particularly in

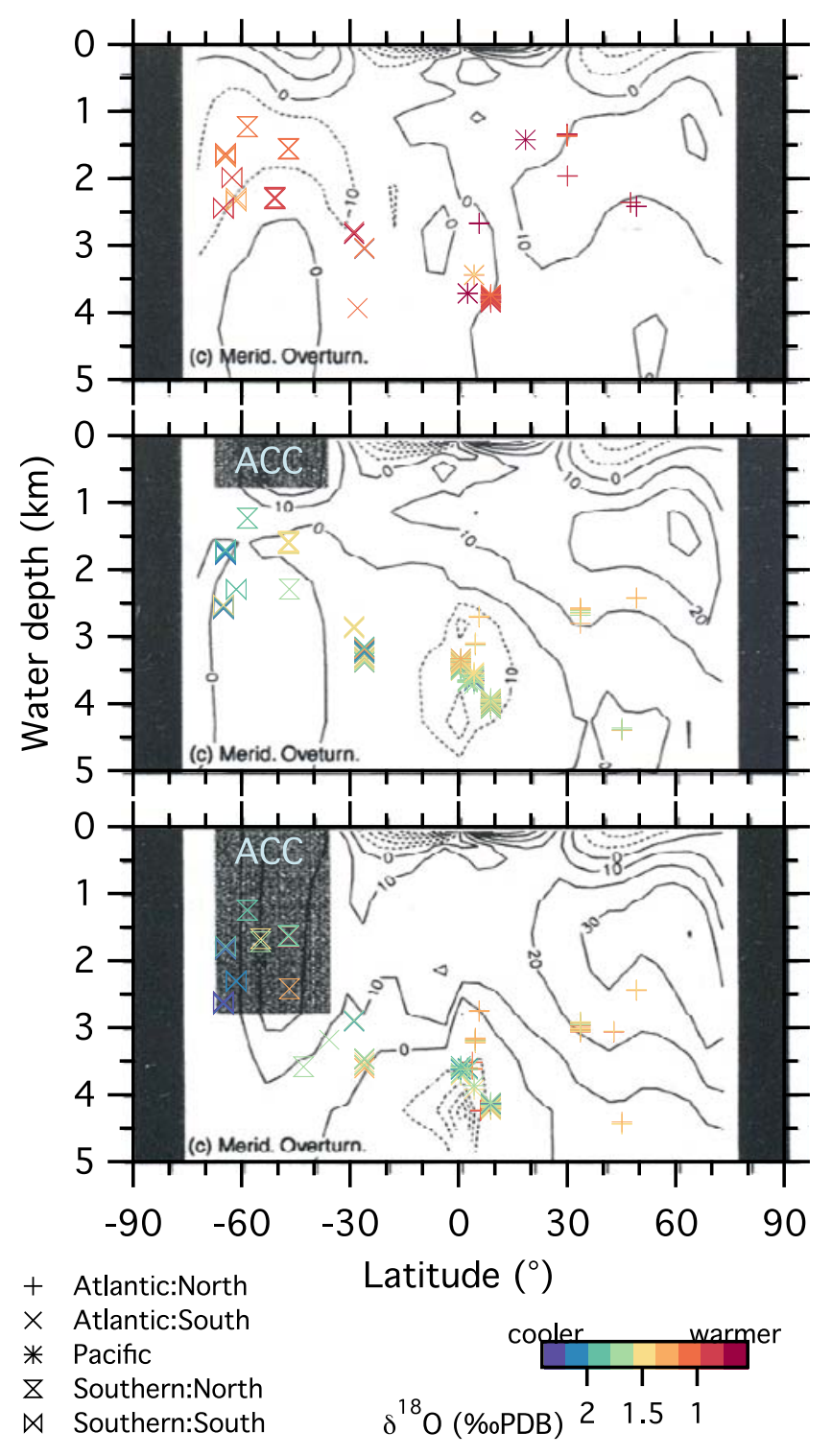

lower deep and bottom waters [Katz et al., 2003b]. The increase in $\delta^{18} \mathrm{O}$ gradients was a long-term shift that persisted throughout the Oligocene and Neogene, but $\delta^{13} \mathrm{C}$ gradients increased only briefly during the Oi-1 event [Miller, 1992].

[24] Three factors are implicated in the increasing $\delta^{13} \mathrm{C}$ gradients from the middle Miocene to the present: (1) deepening of sills surrounding Iceland allowed greater overflow of colder waters to the north, thereby strengthening NCW formation in the North Atlantic [Wright and Miller, 1996; Poore et al., 2006]; (2) shoaling of the Isthmus of Panama increased the salinity of the North Atlantic [Haug and Tiedemann, 1998; Billups, 2002; Lear et al., 2003] and forced a longer deepwater route between the North Atlantic and Pacific [Nisancioglu et al., 2003]; and (3) cooling of the deep ocean favored haline over thermal overturning circulation, thus strengthening NCW formation in the saline North Atlantic at the expense of Pacific NCW formation [de Boer et al., 2008]. The middle Miocene transition (13-10 Ma), accompanied by a turnover in benthic foraminiferal taxa and increased drift deposition in the North Atlantic, is well correlated with an increase in sill depth surrounding Iceland [Wright and Miller, 1996; Poore et al., 2006], whereas the late Miocene-Pliocene transition $(5-7 \mathrm{Ma})$ is better correlated to the closing of the Isthmus of Panama [Lear et al.,

Figure 8. Benthic foraminiferal $\delta^{18} \mathrm{O}$ measurements overlain on sections showing the meridional overturning stream function from ocean general circulation model simulations of Toggweiler and Bjornsson [2000]. Colors of $\delta^{18} \mathrm{O}$ measurements vary from purple for high $\delta^{18} \mathrm{O}$ (e.g., cooler temperatures) to yellow for low $\delta^{18} \mathrm{O}$ (e.g., warmer temperatures). (top) Data points in the range 35-38 Ma overlain on model results for an ocean configuration having no high-latitude passage (e.g., no ACC). (middle) Data points in the range 30-33 Ma overlain on model with a high-latitude passage and shallow (742 $\mathrm{m}$ water depth) ridges obstructing flow. (bottom) Data points in the range 24-27 Ma overlain on model with a high-latitude passage and deep (2768 m water depth) ridges obstructing flow. Depth of unobstructed ACC flow is shown by shaded boxes in middle and bottom plots. With no ACC, circulation is characterized by equatorially symmetric Northern Hemisphere and Southern Hemisphere overturning cells and homogeneous deep ocean temperatures. A shallow ACC results in asymmetric circulation with a warmer, shallow Northern Hemisphere overturning cell and colder Southern Hemisphere deep water production that fills the ocean interior below the depth of ACC flow. A deep ACC restricts the outflow of Southern Hemisphere cold deep water and creates a sharp distinction between temperatures in the high-latitude Southern Ocean and the deep waters north of the ACC. This temperature distinction is a consequence of the net transfer of heat from the Southern Hemisphere to the Northern Hemisphere that results from the ACC, causing surface temperatures in regions of deep water production to be higher in the Northern Hemisphere than in the Southern Hemisphere [Toggweiler and Bjornsson, 2000; Nong et al., 2000; Sijp and England, 2004; Huber et al., 2004]. We show the model stream function results because they are plotted at higher resolution than temperature results shown by Toggweiler and Bjornsson [2000]. 
2003] and cooling of the ocean below $\sim 4^{\circ} \mathrm{C}$ [Lear et al., 2000; Billups and Schrag, 2003] that would favor haline overturning circulation.

\section{Implications for Reorganization of Ocean Overturning Circulation}

[25] Our $\delta^{18} \mathrm{O}$ compilations indicate long-term cooling of the ocean interior and increasing ice volume from the early Eocene to the present (Figure 2), as confirmed by numerous previous studies [Emiliani, 1954, 1961; Shackleton and Kennett, 1975; Savin et al., 1975; Miller et al., 1987a; Zachos et al., 2001; Lear et al., 2000; Billups and Schrag, 2003]. Our interbasinal comparisons reveal that during this same period, the ocean interior switched from a homogeneous to a heterogeneous state (Figure 6), as might be predicted from consideration of the decreased sensitivity of water density to temperature differences in a cold ocean [de Boer et al., 2007]. However, isotopic heterogeneity increased throughout the Oligocene-Miocene, while ocean temperatures remained in the range $\left(>4^{\circ} \mathrm{C}\right)$ of high sensitivity of density to temperature until the middle Miocene [Lear et al., 2000]. In addition, sediment erosion and drift deposition indicates increasingly vigorous deepwater currents during the Oligocene, contrary to the prediction for a colder ocean [de Boer et al., 2007].

[26] We regard the geographic pattern of the $\delta^{18} \mathrm{O}$ differentiation during the Oligocene as a diagnostic characteristic of the development of the ACC (Figure 8). Ocean circulation model experiments strongly support the expectation that most of the ocean's thermal structure would be confined to the upper few hundred meters in an ocean without a circumpolar passage [Cox, 1989; Toggweiler and Samuels, 1998; Toggweiler and Bjornsson, 2000]. The effects of opening the Southern Ocean gateways and allowing circumpolar circulation are (1) to create a barrier to mixing of waters to the north and south of the ACC [Toggweiler and Bjornsson, 2000; Sijp and England, 2004, 2005]; (2) an increase in meridional overturning due to the deep upwelling associated with the ACC [Toggweiler and Samuels, 1998; Toggweiler and Bjornsson, 2000]; and (3) net transfer of heat from the Southern Hemisphere to the Northern Hemisphere, resulting in an increase in sea surface temperature at high northern relative to high southern latitudes [Toggweiler and Bjornsson, 2000; Nong et al., 2000; Sijp and England, 2004; Huber et al., 2004]. The changes in sea surface temperature at high latitudes should be expected to propagate into the deep ocean, and the Oligocene $\delta^{18} \mathrm{O}$ differences of $\sim 0.5 \%$ between the Southern and Pacific oceans and as much as $1 \%$ between the Southern and North Atlantic oceans (Figure 6) are consistent with model results indicating an increase of $4-6^{\circ} \mathrm{C}$ in the sea surface temperature gradient [Toggweiler and Bjornsson, 2000]. While an increase in the temperature differential between NCW and SCW should be expected at the initiation of circumpolar flow, the initially shallow passages in the Southern Ocean would have restricted the ACC to shallow depths and therefore reduced its effectiveness as a barrier to mixing of intermediate and deep waters. This explains the gradual increase in the $\delta^{18} \mathrm{O}$ gradient between high-latitude Southern Ocean and South Atlantic/Subantarctic sites during the Oligo- cene: a shallow circumpolar flow would have been allowed with the opening of the Tasman passage during the late Eocene [Exon et al., 2004; Stickley et al., 2004], but a full depth ACC did not develop until the late Oligocene as the depth of the Drake Passage increased (Figure 8) [Barker and Thomas, 2004; Lyle et al., 2007].

[27] The more homogeneous ocean interior of the early Paleogene reflects a lack of substantial differentiation between northern and southern deepwater source regions that was later enabled by the development of the ACC. Without the strong, localized upwelling associated with the ACC, early Paleogene ocean circulation was likely driven primarily by broad, diffuse upwelling as small-scale turbulent mixing warmed the interior ocean, but warmer temperatures favoring thermal circulation maintained a well-mixed ocean without widespread anoxia. Regions of deepwater formation may have existed in the North and South Pacific as well as the North and South Atlantic, but the nutrient characteristics of these deepwater source regions were similar, resulting in low $\delta^{13} \mathrm{C}$ gradients [see also Sexton et al., 2006]. Generally slightly lower $\delta^{13} \mathrm{C}$ values in the Pacific may reflect an accumulation of older deepwater in the larger Pacific basin, enriched in ${ }^{12} \mathrm{C}$ from the gradual breakdown of organic material sinking from the surface, or it may reflect a higher initial nutrient content of deep water formed in the North Pacific.

[28] It is difficult to imagine an alternative mechanism that could explain the evolution of $\delta^{18} \mathrm{O}$ gradients between the middle Eocene and late Oligocene. A significant increase in the $\delta^{18} \mathrm{O}$ gradients occurred near the Eocene-Oligocene boundary, in conjunction with the formation of the first largescale ice sheet on Antarctica. It is possible that substantial sea ice and increased meridional temperature gradients associated with a continent-scale Antarctic ice sheet may have had a role in the formation of colder SCW [e.g., Miller et al., 2008; Barker and Thomas, 2004], but these factors do not explain the gradual restriction of high $\delta^{18} \mathrm{O}$ deep waters to the high-latitude Southern Ocean or the increased strength of NCW sources indicated by erosional hiatuses in the North Atlantic and the inception of drift sedimentation in the North Atlantic and North Pacific (Figure 6).

\section{Summary and Future Work}

[29] We have reconstructed benthic foraminiferal stable isotopic trends for the North Atlantic, South Atlantic/Subantarctic, high-latitude Southern, and Pacific Ocean basins over the last $80 \mathrm{Myr}$. The differences among these trends differentiate isotopically heterogeneous oceans of the late Paleogene-Neogene and latest Cretaceous from the isotopically homogeneous ocean of the early Paleogene. Large $\delta^{13} \mathrm{C}$ gradients in the Neogene and Late Cretaceous have previously been described and interpreted as indicating changes in the pattern and strength of circulation of deep waters from different source regions. The development of large $\delta^{18} \mathrm{O}$ gradients between the Southern Ocean and other basins between the middle Eocene and late Oligocene has not previously been described. The development of this gradient can be explained as the result of the formation of the ACC with the separation of South America and Australia from 
Antarctica. The timing of the divergence of Southern Ocean $\delta^{18} \mathrm{O}$ values and gradual restriction of the highest $\delta^{18} \mathrm{O}$ values to the high-latitude Southern Ocean corresponds well with the opening of a complete circumpolar passage in the late Eocene and deepening of the Drake Passage through the Oligocene that has been inferred from other evidence [Stickley et al., 2004; Livermore et al., 2007; Lyle et al., 2007].

[30] Our reconstructions suggest that Southern Ocean $\delta^{18} \mathrm{O}$ values began to diverge from the Pacific in the middle Eocene, although the difference between the Southern Ocean and Pacific trends does not reach the $90 \%$ confidence level until the late Eocene (Figure 6). If the thermal differentiation of the Southern Ocean occurred during the middle Eocene, that would imply an effect on deep ocean circulation soon after the opening of a shallow passage between Antarctica and South America and before the separation of Australia from Antarctica allowed a full circumpolar passage. Future work should resolve the evolution of interbasinal $\delta^{18} \mathrm{O}$ gradients during this interval.
[31] The greater heterogeneity of the Late Cretaceous ocean should be examined further; by analogy, we suggest that a wind-driven upwelling engine existed of similar importance to the Neogene ACC. A Tethyan circumequatorial current might have functioned in analogous fashion to the ACC [Hotinski and Toggweiler, 2003], although this idea has been controversial [Poulsen et al., 1998]. Even in the absence of a complete circumequatorial current, the open equatorial expanse may have provided sufficiently strong wind-driven upwelling to enable differentiation between Pacific NCW formation and Atlantic SCW formation. In any case, we find it intriguing that the reduction in isotopic gradients is approximately coeval with the northward drift of India restricting the Tethys.

[32] Acknowledgments. We thank Dennis Kent, Peter Barrett, Ellen Thomas, Philip Sexton, and two anonymous reviewers for useful comments that significantly improved the manuscript. This research was supported in part by NSF grant OCE06-23256.

\section{References}

Alvarez, L., W. Alvarez, F. Asaro, and H. Michel (1980), Extraterrestrial cause for the CretaceousTertiary extinction, Science, 208, 1095-1108, doi:10.1126/science.208.4448.1095.

Barker, P. F., and E. Thomas (2004), Origin, signature and palaeoclimatic influence of the Antarctic Circumpolar Current, Earth Sci. Rev., 66(1-2), $143-162$, doi:10.1016/j.earscirev. 2003.10.003.

Barrera, E., S. M. Savin, E. Thomas, and C. E. Jones (1997), Evidence for thermohalinecirculation reversals controlled by sea-level change in the Latest Cretaceous, Geology, 25(8), 715-718, doi:10.1130/0091-7613 (1997)025<0715:EFTCRC $>2.3 . C O ; 2$.

Bemis, B. E., H. J. Spero, J. Bijma, and D. W. Lea (1998), Reevaluation of the oxygen isotopic composition of planktonic foraminifera: Experimental results and revised paleotemperature equations, Paleoceanography, 13(2), 150-160, doi:10.1029/98PA00070.

Berger, W. H. (2007), Cenozoic cooling, Antarctic nutrient pump, and the evolution of whales, Deep Sea Res., Part II, 54(21-22), 23992421, doi:10.1016/j.dsr2.2007.07.024.

Berger, W. H., and E. Winterer (1974), Plate stratigraphy and the fluctuating carbonate line, Spec. Publ. Int. Assoc. Sedimentol., 1, 11-48.

Billups, K. (2002), Late Miocene through early Pliocene deep water circulation and climate change viewed from the sub-Antarctic South Atlantic, Palaeogeogr. Palaeoclimatol. Palaeoecol., 185(3-4), 287-307, doi:10.1016/S00310182(02)00340-1.

Billups, K., and D. P. Schrag (2003), Application of benthic foraminiferal $\mathrm{Mg} / \mathrm{Ca}$ ratios to questions of Cenozoic climate change, Earth Planet. Sci. Lett., 209, 181-195, doi:10.1016/S0012$821 \mathrm{X}(03) 00067-0$

Bohaty, S. M., and J. C. Zachos (2003), Significant Southern Ocean warming event in the late middle Eocene, Geology, 31(11), 1017-1020, doi:10.1130/G19800.1.

Bohaty, S. M., J. C. Zachos, F. Florindo, and M. L. Delaney (2009), Coupled greenhouse warming and deep-sea acidification in the middle Eocene, Paleoceanography, 24, PA2207, doi:10.1029/2008PA001676.

Broecker, W. (1991), The great ocean conveyor, Oceanography, 4(2), 79-89.
Brückmann, W., M. Čepek, W. W. Hay, T. Matschkowski, E. Soeding, V. Spieß, J. Thiede, R. Tiedemann, and G. Wefer (1999), The Ocean Drilling Stratigraphic Network (www.odsn.de), JOIDES J., 25(1), 2527. (Available at http://www.odplegacy.org/ PDF/Admin/JOIDES Journal/JJ 1999 V25 No1.pdf.)

Cande, S. C., and D. V. Kent (1995), Revised calibration of the geomagnetic polarity timescale for the Late Cretaceous and Cenozoic, J. Geophys. Res., 100(B4), 6093-6095, doi:10.1029/94JB03098.

Cleveland, W. S., and S. J. Devlin (1988), Locally weighted regression: An approach to regression analysis by local fitting, J. Am. Stat. Assoc. 83(403), 596-610, doi:10.2307/2289282.

Corfield, R. M., and R. D. Norris (1996), Deep water circulation in the Paleocene ocean, in Correlation of the Early Paleogene in Northwest Europe, edited by R. W. O'B. Knox, R. M. Corfield, and R. E. Dunay, Geol. Soc. Spec. Publ., 101, 443-456, doi:10.1144/ GSL.SP.1996.101.01.21.

Costa, K. B., F. A. L. Toledo, M. A. G. Pivel, C. A. V. Moura, and F. Chemale Jr. (2006), Evaluation of two genera of benthic foraminifera for down-core paleotemperature studies in the western South Atlantic, Braz. J. Oceanogr., 54, 75-84, doi:10.1590/S167987592006000100007.

Cox, M. D. (1989), An idealized model of the world ocean. Part I: The global-scale water masses, J. Phys. Oceanogr., 19(11), 17301752, doi:10.1175/1520-0485(1989) 019<1730:AIMOTW>2.0.CO;2.

Coxall, H. K., S. D'Hondt, and J. C. Zachos (2006), Pelagic evolution and environmental recovery after the Cretaceous-Paleogene mass extinction, Geology, 34(4), 297-300, doi:10.1130/G21702.1.

Culver, S. J. (2003), Benthic foraminifera across the Cretaceous-Tertiary (K-T) boundary: A review, Mar. Micropaleontol., 47(3), 177-226, doi:10.1016/S0377-8398(02)00117-2.

Curry, W. B., and G. P. Lohmann (1982), Carbon isotopic changes in benthic foraminifera from the western South Atlantic: Reconstruction of glacial abyssal circulation patterns, Quat. Res.,
18(2), 218-235, doi:10.1016/0033-5894(82) 90071-0.

de Boer, A. M., D. M. Sigman, J. R. Toggweiler, and J. L. Russell (2007), Effect of global ocean temperature change on deep ocean ventilation, Paleoceanography, 22, PA2210, doi:10.1029/ 2005 PA001242.

de Boer, A. M., J. R. Toggweiler, and D. M. Sigman (2008), Atlantic dominance of the meridional overturning circulation, J. Phys. Oceanogr., 38(2), 435-450, doi:10.1175/ 2007JPO3731.1.

D’Hondt, S., P. Donaghay, J. Zachos, D. Luttenberg, and M. Lindinger (1998), Organic carbon fluxes and ecological recovery from the Cretaceous-Tertiary mass extinction, Science, 282, 276-279, doi:10.1126/science.282.5387. 276.

Emiliani, C. (1954), Temperatures of Pacific bottom waters and polar superficial waters during the Tertiary, Science, 119, 853-855, doi:10.1126/science.119.3103.853.

Emiliani, C. (1961), The temperature decrease of surface sea-water in high latitudes and of abyssal-hadal water in open oceanic basins during the past 75 million years, Deep Sea Res., 8(2), 144-147, doi:10.1016/01466313(61)90006-5.

Exon, N., J. Kennett, and M. Malone (2004), Leg 189 synthesis: Cretaceous-Holocene history of the Tasmanian Gateway, in Proc. Ocean Drill. Program Sci. Results, 189, 1-37, doi:10.2973/ odp.proc.sr.189.101.2004.

Flower, B., and J. Kennett (1994), The middle Miocene climatic transition: East Antarctic ice sheet development, deep ocean circulation and global carbon cycling, Palaeogeogr. Palaeoclimatol. Palaeoecol., 108(3-4), 537-555, doi:10.1016/0031-0182(94)90251-8.

Frank, T. D., and M. A. Arthur (1999), Tectonic forcings of Maastrichtian ocean-climate evolution, Paleoceanography, 14(2), 103-117, doi:10.1029/1998PA900017.

Gradstein, F. M., J. G. Ogg, and A. G. Smith (2004), A Geologic Time Scale 2004, doi:10.2277/0511074050, Cambridge Univ. Press, Cambridge, U. K.

Haug, G. H., and R. Tiedemann (1998), Effect of the formation of the Isthmus of Panama on 
Atlantic Ocean thermohaline circulation, Nature, 393, 673-676, doi:10.1038/31447.

Hay, W., et al. (1999), Alternative global Cretaceous paleogeography, in The Evolution of Cretaceous Ocean/Climate Systems, edited by E. Barrera and C. Johnson, Spec. Pap. Geol. Soc. Am., 332, 1-47.

Hayward, B. W., S. Kawagata, H. R. Grenfell, A. T. Sabaa, and T. O’Neill (2007), Last global extinction in the deep sea during the midPleistocene climate transition, Paleoceanography, 22, PA3103, doi:10.1029/2007PA001424.

Hildebrand, A. R., G. T. Penfield, D. A. Kring, M. Pilkington, A. Z. Camargo, S. B. Jacobsen, and W. V. Boynton (1991), Chicxulub Crater: A possible Cretaceous/Tertiary boundary impact crater on the Yucatán Peninsula, Mexico, Geology, 19(9), 867-871, doi:10.1130/00917613(1991)019<0867:CCAPCT > 2.3.CO;2.

Hotinski, R. M., and J. R. Toggweiler (2003), Impact of a Tethyan circumglobal passage on ocean heat transport and "equable" climates, Paleoceanography, 18(1), 1007, doi:10.1029/ 2001PA000730.

Huber, M., H. Brinkhuis, C. E. Stickley, K. Döís, A. Sluijs, J. Warnaar, S. A. Schellenberg, and G. L. Williams (2004), Eocene circulation of the Southern Ocean: Was Antarctica kept warm by subtropical waters?, Paleoceanography, 19, PA4026, doi:10.1029/2004PA001014.

Katz, M. E., D. K. Pak, G. R. Dickens, and K. G. Miller (1999), The source and fate of massive carbon input during the latest Paleocene thermal maximum, Science, 286, 1531-1533, doi:10.1126/science. 286.5444 .1531

Katz, M. E., D. R. Katz, J. D. Wright, K. G. Miller, D. K. Pak, N. J. Shackleton, and E. Thomas (2003a), Early Cenozoic benthic foraminiferal isotopes: Species reliability and interspecies correction factors, Paleoceanography, 18(2), 1024, doi:10.1029/2002PA000798.

Katz, M. E., R. C. Tjalsma, and K. G. Miller (2003b), Oligocene bathyal to abyssal benthic foraminifera of the Atlantic Ocean, Micropaleontology, 49, suppl. 2, 1-45, doi:10.2113/ 49.Suppl 2.1.

Katz, M. E., Z. V. Finkel, D. Grzebyk, A. H. Knoll, and P. G. Falkowski (2004), Evolutionary trajectories and biogeochemical impacts of marine eukaryotic phytoplankton, Annu. Rev. Ecol. Evol. Syst., 35(1), 523-556, doi:10.1146/ annurev.ecolsys.35.112202.130137.

Katz, M. E., J. D. Wright, K. G. Miller, B. S. Cramer, K. Fennel, and P. G. Falkowski (2005), Biological overprint of the geological carbon cycle, Mar. Geol., 217, 323-338, doi:10.1016/j.margeo.2004.08.005.

Kennett, J. P. (1977), Cenozoic evolution of Antarctic glaciation, the circum-Antarctic Ocean, and their impact on global paleoceanography, J. Geophys. Res., 82(27), 3843-3860, doi:10.1029/JC082i027p03843.

Kennett, J. P., and L. D. Stott (1991), Abrupt deep-sea warming, palaeoceanographic changes and benthic extinctions at the end of the Palaeocene, Nature, 353, 225-229, doi: $10.1038 / 353225 \mathrm{a} 0$.

Lear, C. H., H. Elderfield, and P. A. Wilson (2000), Cenozoic deep-sea temperatures and global ice volumes from $\mathrm{Mg} / \mathrm{Ca}$ in benthic foraminiferal calcite, Science, 287, 269-272, doi:10.1126/science.287.5451.269.

Lear, C. H., Y. Rosenthal, and J. D. Wright (2003), The closing of a seaway: Ocean water masses and global climate change, Earth Planet. Sci. Lett., 210, 425-436, doi:10.1016/ S0012-821X(03)00164-X
Livermore, R., C.-D. Hillenbrand, M. Meredith, and G. Eagles (2007), Drake Passage and Cenozoic climate: An open and shut case?, Geochem. Geophys. Geosyst., 8, Q01005, doi: $10.1029 / 2005$ GC001224.

Lyle, M., A. Olivarez Lyle, J. Backman, and A. Tripati (2006), Biogenic sedimentation in the Eocene equatorial Pacific-The stuttering greenhouse and Eocene carbonate compensation depth, Proc. Ocean Drill. Program Sci. Results, 199, 1-35, doi:10.2973/odp.proc. sr.199.219.2005.

Lyle, M., S. Gibbs, T. C. Moore, and D. K. Rea (2007), Late Oligocene initiation of the Antarctic Circumpolar Current: Evidence from the South Pacific, Geology, 35(8), 691-694, doi:10.1130/G23806A.1

Miller, K. (1992), Middle Eocene to Oligocene stable isotopes, climate, and deep-water history: The terminal Eocene event?, in EoceneOligocene Climatic and Biotic Evolution, edited by D. R. Prothero and W. A. Berggren, pp. 160 177, Princeton Univ. Press, Princeton, N. J.

Miller, K., and B. Tucholke (1983), Development of Cenozoic abyssal circulation south of the Greenland-Scotland Ridge, in Structure and Development of the Greenland-Scotland Ridge: New Methods and Concepts, edited by M. Bott et al., NATO Conf. Ser. IV, 8, 549-589.

Miller, K. G., R. G. Fairbanks, and G. S. Mountain (1987a), Tertiary oxygen isotope synthesis, sea level history, and continental margin erosion, Paleoceanography, 2(1), 1-19, doi:10.1029/PA002i001p00001.

Miller, K., R. Fairbanks, and E. Thomas (1987b), Benthic foraminiferal carbon isotopic records and the development of abyssal circulation in the eastern North Atlantic, Proc. Ocean Drill. Program Initial Rep., 94, 981-996, doi:10.2973/dsdp.proc.94.132.1987.

Miller, K. G., J. D. Wright, and R. G. Fairbanks (1991), Unlocking the ice house: OligoceneMiocene oxygen isotopes, eustasy, and margin erosion, J. Geophys. Res., 96(B4), 6829-6848, doi:10.1029/90JB02015.

Miller, K., M. Katz, and W. Berggren (1992), Cenozoic deep-sea benthic foraminifera: A tale of three turnovers, in Studies in Benthic Foraminifera: Proceedings of the Fourth International Symposium on Benthic Foraminifera, Sendai, 1990, edited by Y. Takayanagi and T. Saito, pp. 67-75, Tokai Univ. Press, Tokyo.

Miller, K. G., E. Barrera, R. K. Olsson, P. J. Sugarman, and S. M. Savin (1999), Does ice drive early Maastrichtian eustasy?, Geology, 27(9), 783-786, doi:10.1130/0091-7613(1999) 027<0783:DIDEME $>2.3 . C O ; 2$

Miller, K. G., J. D. Wright, M. E. Katz, J. V. Browning, B. S. Cramer, B. S. Wade, and S. F. Mizintseva (2008), A view of Antarctic ice-sheet evolution from sea-level and deep-sea isotope changes during the Late CretaceousCenozoic, in Antarctica: A Keystone in a Changing World-Proceedings of the 10th International Symposium on Antarctic Earth Sciences, edited by A. Cooper et al., pp. 5570, Natl. Acad., Washington, D. C.

Mountain, G. S., and K. G. Miller (1992), Seismic and geologic evidence for early Paleogene deepwater circulation in the western North Atlantic, Paleoceanography, 7(4), 423-439, doi:10.1029/92PA01268.

Nisancioglu, K. H., M. E. Raymo, and P. H. Stone (2003), Reorganization of Miocene deep water circulation in response to the shoaling of the Central American Seaway, Paleoceanography, 18(1), 1006, doi:10.1029/2002PA000767.
Nong, G. T., R. G. Najjar, D. Seidov, and W. H. Peterson (2000), Simulation of ocean temperature change due to the opening of Drake Passage, Geophys. Res. Lett., 27(17), 2689-2692, doi:10.1029/1999GL011072.

Oppo, D. W., and R. G. Fairbanks (1987), Variability in the deep and intermediate water circulation of the Atlantic Ocean during the past 25000 years: Northern Hemisphere modulation of the Southern Ocean, Earth Planet. Sci. Lett., 86, 1-15, doi:10.1016/0012-821X(87)90183-X.

Pak, D. K., and K. G. Miller (1992), Paleocene to Eocene benthic foraminiferal isotopes and assemblages: Implications for deepwater circulation, Paleoceanography, 7(4), 405-422, doi:10.1029/92PA01234

Parsons, B., and J. G. Sclater (1977), An analysis of the variation of ocean floor bathymetry and heat flow with age, J. Geophys. Res., 82(5), 803-827, doi:10.1029/JB082i005p00803.

Pekar, S. F., R. M. DeConto, and D. M. Harwood (2006), Resolving a late Oligocene conundrum: Deep-sea warming and Antarctic glaciation, Palaeogeogr. Palaeoclimatol. Palaeoecol. 231(1-2), 29-40, doi:10.1016/j.palaeo.2005. 07.024 .

Poore, H. R., R. Samworth, N. J. White, S. M Jones, and I. N. McCave (2006), Neogene overflow of northern component water at the Greenland-Scotland Ridge, Geochem. Geophys. Geosyst., 7, Q06010, doi:10.1029/ 2005GC001085.

Poulsen, C. J., D. Seidov, E. J. Barron, and W. H. Peterson (1998), The impact of paleogeographic evolution on the surface oceanic circulation and the marine environment within the mid-Cretaceous Tethys, Paleoceanography, 13(5), 546-558, doi:10.1029/98PA01789.

Ravizza, G. E., and J. C. Zachos (2003), Records of Cenozoic ocean chemistry, in Treatise on Geochemistry, edited by H. D. Holland and K. K. Turekian, pp. 551-581, doi:10.1016/ B0-08-043751-6/06121-1, Pergamon, Oxford, U. K

Rea, D. K., I. A. Basov, L. A. Krissek, and the Leg 145 Scientific Party (1995), Scientific results of drilling the North Pacific transect, Proc. Ocean Drill. Program Sci. Results, 145, 577-596, doi:10.2973/odp.proc.sr.145. 146.1995.

Rosenthal, Y., E. A. Boyle, and L. Labeyrie (1997), Last Glacial Maximum paleochemistry and deepwater circulation in the Southern Ocean: Evidence from foraminiferal cadmium, Paleoceanography, 12(6), 787-796, doi:10.1029/ 97PA02508.

Savin, S. M., R. G. Douglas, and F. G. Stehli (1975), Tertiary marine paleotemperatures, Geol. Soc. Am. Bull., 86(11), 1499-1510, doi:10.1130/0016-7606(1975)86<1499:TMP> 2.0.CO;2.

Scher, H. D., and E. E. Martin (2004), Circulation in the Southern Ocean during the Paleogene inferred from neodymium isotopes, Earth Planet. Sci. Lett., 228, 391-405, doi:10.1016/ j.epsl.2004.10.016.

Scher, H. D., and E. E. Martin (2006), Timing and climatic consequences of the opening of Drake Passage, Science, 312, 428-430, doi:10.1126/science.1120044.

Schumacher, S., and D. Lazarus (2004), Regional differences in pelagic productivity in the late Eocene to early Oligocene-A comparison of southern high latitudes and lower latitudes, Palaeogeogr. Palaeoclimatol. Palaeoecol. 214(3), 243-263, doi:10.1016/j.palaeo.2004. 06.018 
Sclater, J. G., R. N. Anderson, and M. L. Bell (1971), Elevation of ridges and evolution of the central eastern Pacific, J. Geophys. Res., 76(32), 7888-7915, doi:10.1029/JB076i032p07888.

Sexton, P. F., P. A. Wilson, and R. D. Norris (2006), Testing the Cenozoic multisite composite $\delta^{18} \mathrm{O}$ and $\delta^{13} \mathrm{C}$ curves: New monospecific Eocene records from a single locality, Demerara Rise (Ocean Drilling Program Leg 207), Paleoceanography, 21, PA2019, doi:10.1029/ 2005PA001253.

Shackleton, N. J. (1974), Attainment of isotopic equilibrium between ocean water and the benthonic foraminifera genus Uvigerina: Isotopic changes in the ocean during the last glacial, Colloq. Int. C. N. R. S., 219, 203-209.

Shackleton, N. J., and J. P. Kennett (1975), Paleotemperature history of the Cenozoic and the initiation of Antarctic glaciation: Oxygen and carbon isotope analyses in DSDP Sites 277, 279, and 281, Initial Rep. Deep Sea Drill. Proj., 29, 743-755, doi:10.2973/dsdp.proc. 29.117.1975.

Shackleton, N. J., et al. (1984), Oxygen isotope calibration of the onset of ice-rafting and history of glaciation in the North Atlantic region, Nature, 307, 620-623, doi:10.1038/307620a0.

Sijp, W. P., and M. H. England (2004), Effect of the Drake Passage throughflow on global climate, J. Phys. Oceanogr., 34(5), 1254-1266, doi:10.1175/1520-0485(2004)034<1254: EOTDPT $>2.0 . \mathrm{CO} ; 2$

Sijp, W. P., and M. H. England (2005), Role of the Drake Passage in controlling the stability of the ocean's thermohaline circulation, J. Clim., 18(12), 1957-1966, doi:10.1175/ JCLI3376.1.

Sluijs, A., G. Bowen, H. Brinkhuis, L. Lourens, and E. Thomas (2007), The PalaeoceneEocene thermal maximum super greenhouse: Biotic and geochemical signatures, age models and mechanisms of global change, in DeepTime Perspectives on Climate Change: Marrying the Signal From Computer Models and Biological Proxies, Micropalaeontological Society Special Publications, edited by M. Williams et al., pp. 323-349, Geol. Soc., London.

Stein, C. A., and S. Stein (1992), A model for the global variation in oceanic depth and heat flow with lithospheric age, Nature, 359, 123-129, doi: $10.1038 / 359123 \mathrm{a} 0$.

Stickley, C. E., H. Brinkhuis, S. A. Schellenberg, A. Sluijs, U. Röhl, M. Fuller, M. Grauert, M. Huber, J. Warnaar, and G. L. Williams (2004), Timing and nature of the deepening of the Tasmanian Gateway, Paleoceanography, 19, PA4027, doi:10.1029/2004PA001022.

Thomas, D. J. (2004), Evidence for deep-water production in the North Pacific Ocean during the early Cenozoic warm interval, Nature, 430, 65-68, doi:10.1038/nature02639.
Thomas, D. J., T. J. Bralower, and C. E. Jones (2003), Neodymium isotopic reconstruction of late Paleocene-early Eocene thermohaline circulation, Earth Planet. Sci. Lett., 209, 309322, doi:10.1016/S0012-821X(03)00096-7.

Thomas, D. J., M. Lyle, T. C. Moore Jr., and D. K. Rea (2008), Paleogene deepwater mass composition of the tropical pacific and implications for thermohaline circulation in a greenhouse world, Geochem. Geophys. Geosyst., 9, Q02002, doi:10.1029/2007GC001748.

Thomas, E. (1992a), Cenozoic deep-sea circulation: Evidence from deep-sea benthic foraminifera, in The Antarctic Paleoenvironment: A Perspective on Global Change, Antarct. Res. Ser., vol. 56, edited by J. P. Kennett and D. A Warnke, pp. 141-165, AGU, Washington, D. C

Thomas, E. (1992b), Middle Eocene-late Oligocene bathyal benthic foraminifera (Weddell Sea): Faunal changes and implications for ocean circulation, in Eocene-Oligocene Climatic and Biotic Evolution, edited by D. R. Prothero and W. A. Berggren, pp. 245-271, Princeton Univ. Press, Princeton, N. J.

Thomas, E. (1998), Biogeography of the late Paleocene benthic foraminiferal extinction, in Late Paleocene-Early Eocene Climatic and Biotic Events in the Marine and Terrestrial Records, edited by M.-P. Aubry, S. Lucas, and W. Berggren, pp. 214-243, Columbia Univ. Press, New York.

Thomas, E. (2007), Cenozoic mass extinctions in the deep sea: What perturbs the largest habitat on Earth?, in Large Ecosystem Perturbations: Causes and Consequences, edited by S. Monechi, R. Coccioni, and M. R. Rampino, Spec. Pap. Geol. Soc. Am., 424, 1-24.

Thomas, E., and A. J. Gooday (1996), Cenozoic deep-sea benthic foraminifers: Tracers for changes in oceanic productivity?, Geology, 24(4), 355-358, doi:10.1130/0091-7613 (1996) $024<0355:$ CDSBFT $>2.3 . \mathrm{CO} ; 2$

Thomas, E., and N. J. Shackleton (1996), The Paleocene-Eocene benthic foraminiferal extinction and stable isotope anomalies, in Correlation of the Early Paleogene in Northwest Europe, edited by R. W. O'B. Knox, R. M. Corfield, and R. E. Dunay, Geol. Soc. Spec. Publ., 101, 401-441, doi:10.1144/GSL.SP. 1996.101.01.20

Tjalsma, R., and G. Lohmann (1983), PaleoceneEocene Bathyal and Abyssal Benthic Foraminifera From the Atlantic Ocean, Micropaleontol. Spec. Publ., 4, 90 pp.

Toggweiler, J. R., and H. Bjornsson (2000), Drake Passage and palaeoclimate, J. Quat Sci., 15(4), 319-328, doi:10.1002/1099-1417 (200005) 15:4<319::AID-JQS545>3.0.CO;2-C

Toggweiler, J. R., and B. Samuels (1998), On the ocean's large-scale circulation near the limit of no vertical mixing, J. Phys. Oceanogr., 28(9) 1832-1852, doi:10.1175/1520-0485(1998) $028<1832$ :OTOSLS $>2.0 . \mathrm{CO} ; 2$.

Wold, C. N. (1994), Cenozoic sediment accumulation on drifts in the northern North Atlantic Paleoceanography, 9(6), 917-942, doi:10.1029/94PA01438.

Woodruff, F., and S. M. Savin (1989), Miocene deepwater oceanography, Paleoceanography, 4(1), 87-140, doi:10.1029/PA004i001p00087.

Wright, J. D., and K. G. Miller (1993), Southern Ocean influences on late Eocene to Miocene deepwater circulation, in The Antarctic Paleoenvironment: A Perspective on Global Change, Antarct. Res. Ser., vol. 60, edited by J. P. Kennett and D. A. Warnke, pp. 1-25, AGU, Washington, D. C.

Wright, J. D., and K. G. Miller (1996), Control of North Atlantic deep water circulation by the Greenland-Scotland Ridge, Paleoceanography, 11(2), 157-170, doi:10.1029/95PA03696.

Wright, J. D., K. G. Miller, and R. G. Fairbanks (1991), Evolution of modern deepwater circulation: Evidence from the late Miocene Southern Ocean, Paleoceanography, 6(2), 275-290, doi:10.1029/90PA02498.

Wright, J. D., K. G. Miller, and R. G. Fairbanks (1992), Early and middle Miocene stable isotopes: Implications for deepwater circulation and climate, Paleoceanography, 7(3), 357-389, doi:10.1029/92PA00760.

Wunsch, C. (2002), What is the thermohaline circulation?, Science, 298, 1179-1181, doi:10.1126/science.1079329.

Zachos, J. C., J. R. Breza, and S. M. Wise (1992), Early Oligocene ice-sheet expansion on Antarctica: Stable isotope and sedimentological evidence from Kerguelen Plateau, southern Indian Ocean, Geology, 20(6), 569-573 doi:10.1130/0091-7613(1992)020<0569:EOI$\mathrm{SEO}>2.3 . \mathrm{CO} ; 2$

Zachos, J., M. Pagani, L. Sloan, E. Thomas, and K. Billups (2001), Trends, rhythms, and aberrations in global climate $65 \mathrm{Ma}$ to present, Science 292, 686-693, doi:10.1126/science.1059412.

Zachos, J. C., G. R. Dickens, and R. E. Zeebe (2008), An early Cenozoic perspective on greenhouse warming and carbon-cycle dynamics, $\mathrm{Nat}$ ure, 451, 279-283, doi:10.1038/nature06588.

B. S. Cramer, Theiss Research, 1214 W. 17th Ave., Eugene, OR 97402, USA. (b.s.cramer@ theissresearch.org)

M. E. Katz, Department of Earth and Environmental Science, Rensselaer Polytechnic Institute, Troy, NY 12180, USA.

K. G. Miller and J. D. Wright, Department of Earth and Planetary Sciences, Rutgers University, Piscataway, NJ 08854, USA.

J. R. Toggweiler, Geophysical Fluid Dynamics Laboratory, NOAA, Princeton, NJ 08542, USA. 